\title{
THE SIGNIFICANCE OF METHAEMOGLOBINAEMIA INDUCED BY PRILOCAINE (CITANEST) ${ }^{\bullet}$
}

\author{
W. E. SPOEREL, M.D., F.R.C.P.(c), D. H. ADAMSON, M.B., CH.B., AND
}

R. S. EBERHAFD $\nmid$

Prmocanne (Citanest) has been recently introduced as a new local anaesthetic agent. Its main advantage is a low central nervous system toxicity; the duration of action is slightly longer than that of lidocaine (Xylocaine). In the course of clinical trials it was noted that patients became cyanotic some time after the administration of prilocaine, and several investigators have confirmed that methaemoglobin is the cause of this cyanosis. ${ }^{1}$ It has been demonstrated that the level of methaemoglobinaemia was directly related to the dosage of prilocaine. A time lag between the peak concentration of prilocaine in blood and the maximum methaemoglobin concentration suggested that the cause was likely a metabolite of prilocaine. With a duration of anaesthesia of approximately two and one-half hours (Fig. 1), the maximum methaemoglobin formation was

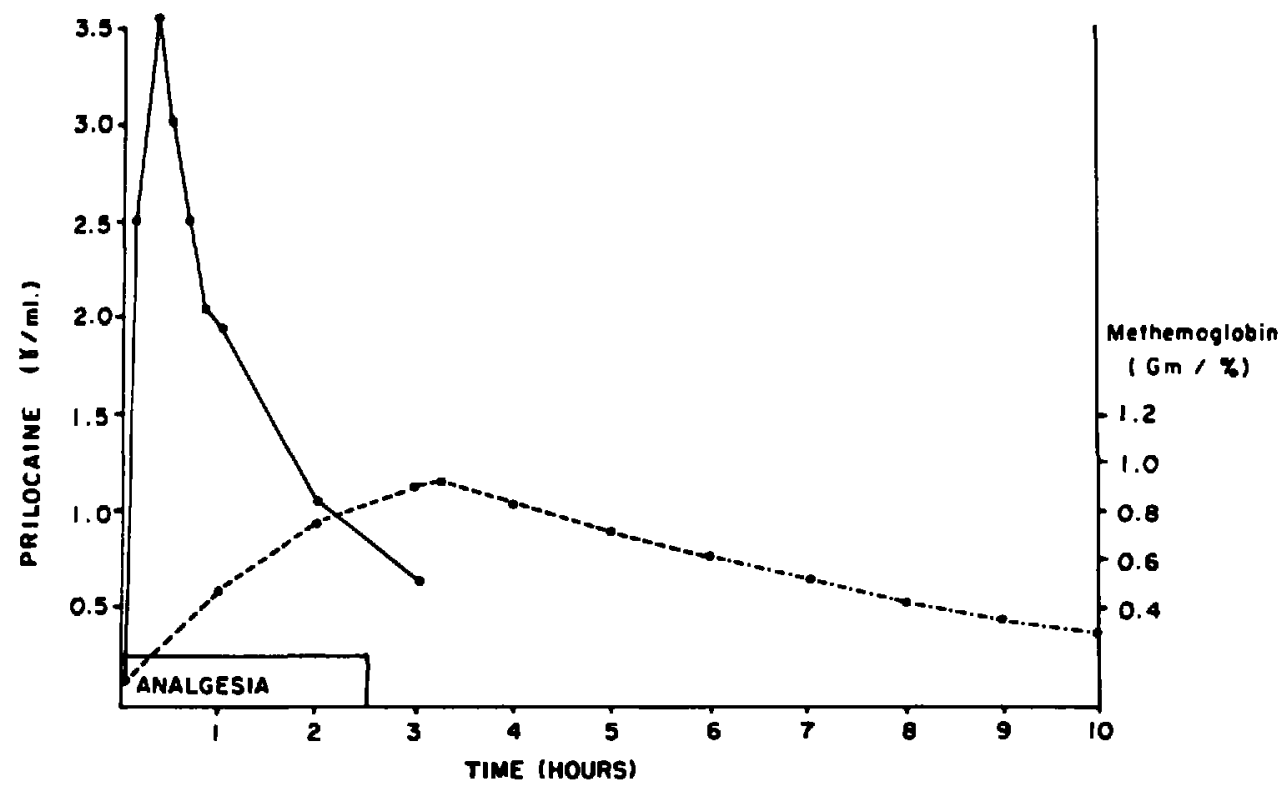

Figure 1. Blood levels of prilocaine (Citanest) after injection of $600 \mathrm{mg} .4$ are shown by the sharply peaked line at left. Methaemoglobin levels (mean of cases) 11 are shown by the dashed line.

"Presented at the Annual Meeting of the Canadian Anaesthetists' Society at Banff, June 6 to 10,1966 .

fDr. Spoerel and Dr. Adamson are in the Department of Anaesthesia, University of Western Ontario, London, Ontario. Mr. Eberhard is a medical student at the University of Western Ontario. 
reached between three to four hours after an injection and, depending on the dosage, an elevated methaemoglobin could be observed as long as 14 hours in our own cases. ${ }^{2}$ No methaemoglobin was observed after the incubation of prilocaine with whole blood. ${ }^{3}$ In order to avoid cyanosis it is recommended that a dose of $600 \mathrm{mg}$. not be exceeded; this would keep the methaemoglobin formation below 15 per cent of total haemoglobin.

Our assessment of the significance of the methaemoglobin formation caused by prilocaine is based on reports from the literature ${ }^{1,3,4}$ and on observations on 76 cases, ${ }^{2,11}$ mostly with epidural analgesia but also some brachial blocks. Methaemoglobin was determined according to the method of Evelyn and Malloy. ${ }^{5}$ All our determinations were done within a few minutes after the blood was obtained.

Methaemoglobin is formed by the oxidation of haemoglobin, converting the ferrous porphyrin complex into the ferric form ( $\mathrm{Hb} \mathrm{Fe}+++\mathrm{OH})$. In this state oxygen cannot be accepted; the oxygen-carrying capacity is therefore reduced according to the amount of methaemoglobin present. In addition there is a shift in the oxygen dissociation curve of the remaining haemoglobin (Fig. 2), hindering the unloading of oxygen at the tissue level. ${ }^{6}$ Reconversion to the ferrous state is possibly due to a "reductase"; for its function intact erythrocyte and glucose are required.

The amount of methaemoglobin is related to the causative agent but not to the haemoglobin level itself. We prefer to report our results in gm. per cent of methaemoglobin present rather than in per cent, as some investigators have done; $^{1}$ the latter may lead to the false assumption that anaemic patients form proportionately less methaemoglobin.

The level of methaemoglobin is determined by the metabolic step leading to the formation of an intermediary compound and by the activity of an enzyme system reconverting methaemoglobin to haemoglobin. Onji and Tyuma ${ }^{1}$ have

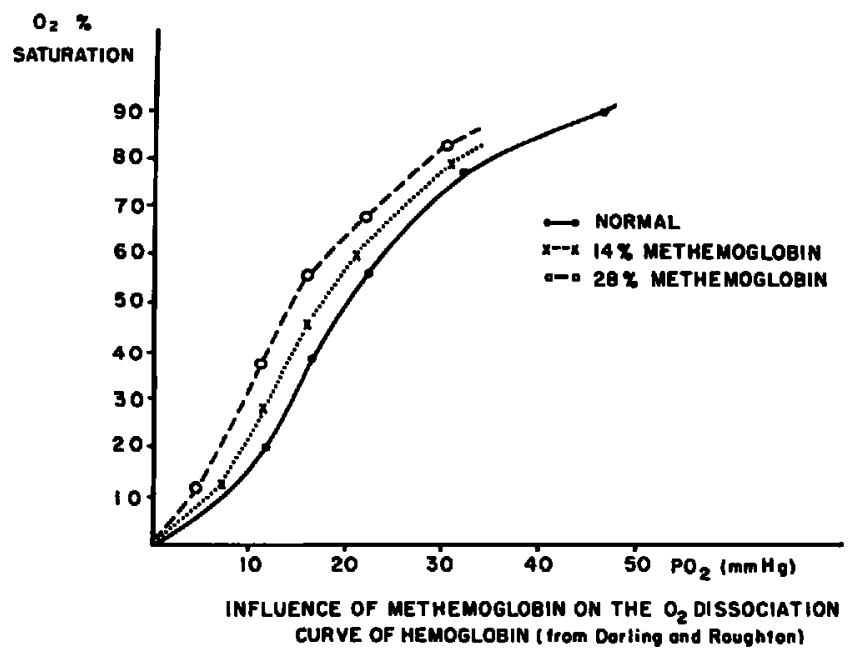

FIGURE 2 
proposed that ortho-toluidine may be the intermediary compound (Fig. 3). This assumption is based on the similarity of characteristics of the two compounds, and particularly on the observation that the molecular ratio of prilocaine and ortho-toluidine are identical.

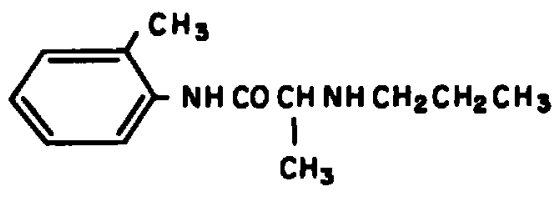

PRILOCAINE

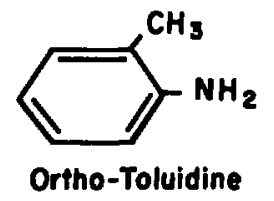

Figure 3

The maximum level of methaemoglobin is related to the dosage of prilocaine (Fig. 4), although there are considerable individual variations. This level correlated best with the dosage of prilocaine per square metre surface area $(r=0.78)$. Since the causative agent is a metabolite of prilocaine, any dosage

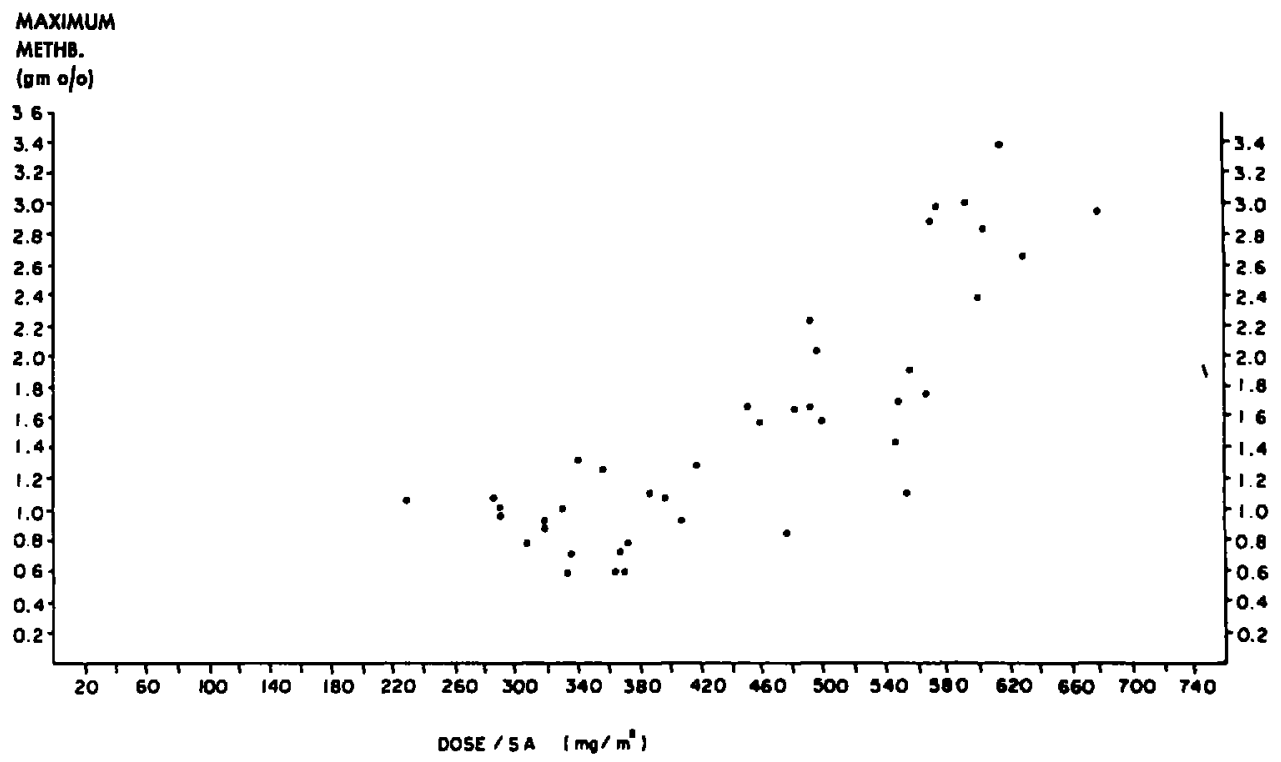

Figune 4. Maximum methaemoglobin content in relation to dosage of prilocaine (in $\left.\mathrm{mg} . / \mathrm{m} .^{2}\right),{ }^{11}$ 
injected will produce methaemoglobin; with very small doses this may not exceed significantly the usually present level of about 0.1 to $0.2 \mathrm{gm}$. per cent.

There are certain discrepancies concerning the amount of methaemoglobin produced by a given dose of prilocaine (Fig. 5). Results reported from studies in the United States showed generally lower levels than those from Sweden and Japan..$^{1,4}$ Our own results ${ }^{11}$ are in agreement with the latter and incidentally agree with values reported in cats. ${ }^{7}$ We have not been able to observe a significant difference in methaemoglobin production in cats between the prilocaine produced in the United States and that marketed in Canada. However, differences in the time interval between the sampling and the determination of methaemoglobin are important. The methaemoglobin content of blood standing at room temperature for two hours would be only 62 per cent; that of refrigerated blood 75 per cent of the original value. ${ }^{11}$ Our own determinations agreed with the clinical observation of cyanosis which is obvious above $1.5 \mathrm{gm}$. per cent methaemoglobin; astute observers will detect colour changes already above $0.8 \mathrm{gm}$. per cent.

It is recommended that a dosage of $600 \mathrm{mg}$. should not be exceeded in order to avoid the formation of significant amounts of methaemoglobin. In 20 patients we found after $600 \mathrm{mg}$. an average maximum content of $0.93 \mathrm{gm}$. per cent $( \pm 0.14$ ), and $1.89 \mathrm{gm}$. per cent $( \pm 0.40$ ) after an injection of $900 \mathrm{mg}$. in 11 patients. Although the latter level will certainly produce cyanosis in all patients, there is no demonstrable clinical effect of such methaemoglobin concentrations in normal patients, and only in severely anaemic patients would such levels be critical. In order to observe clinical signs or compensatory changes of the circulation, much higher methaemoglobin levels are required, due to the great reserve of oxygen transport. With over 30 per cent methaemoglobin exertional dyspnoea has been observed, and fatigue and headache may occur. Signs of

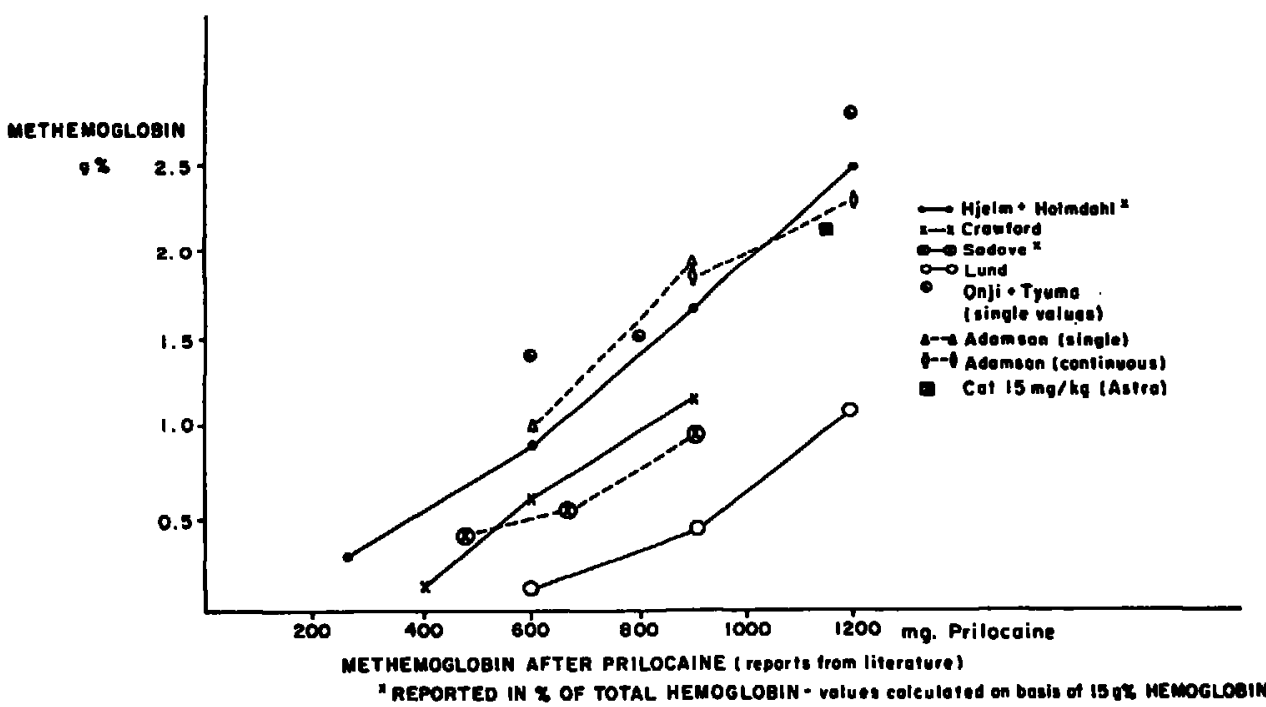

Frguns 51,4,7,11 
cerebral hypoxia may appear with 60 per cent methaemoglobin, while 80 per cent leads to unconsciousness and higher levels are fatal. ${ }^{\circ}$ In dogs with normal haemoglobin levels the cardiac output rose significantly when methaemoglobin reduced the oxygen content of arterial blood to about 10 vol. per cent; when such reduction was caused by anaemia, the cardiac output remained unchanged. ${ }^{8}$ In patients at rest and with a normal range of haemoglobin, 3 to $4 \mathrm{gm}$. per cent methaemoglobin are therefore very unlikely to have a noticeable effect other than the rather ghastly bluish grey appearance of the patient.

Should there be concern about the cyanosed appearance of the patient, we are assured that 1 to $2 \mathrm{mg} . / \mathrm{kg}$. of methylene blue will reverse the methaemoglobinaemia very quickly and we have convinced ourselves that this is effective. Yet we are not convinced that cyanosis is always recognized; the attention of the observing nurse or physician must be directed towards the expected change in colour. An experienced nurse who attended a patient several times during the hour prior to our questioning reassured us that she had not noticed anything abnormal. She even denied the possibility of a colour change until she was again confronted -with the patient; only then did the cyanosis become apparent to her. At that time the patient had about $5 \mathrm{gm}$. per cent methaemoglobin. It is therefore questioned whether the observation of cyanosis and the subsequent treatment with methylene blue is a sufficiently certain remedy to dismiss any further consideration of the consequences of methaemoglobin. Methylene blue itself is not altogether harmless, and haemolytic anaemia has been described after larger doses. ${ }^{10}$

As indicated earlier, the appearance and disappearance of methaemoglobin is a rather slow process taking about 12 hours following an injection of $600 \mathrm{mg}$. Therefore a cumulative effect may be expected. The injection of $900 \mathrm{mg}$. in divided doses, i.e., $300 \mathrm{mg}$. followed by three hourly injections of $200 \mathrm{mg}$., did, in effect, produce the same methaemoglobin level as a single injection of $900 \mathrm{mg}$,, only the maximum methaemoglobin concentration occurred after six hours as compared to four hours with the single injection. ${ }^{11}$

The methaemoglobin curve following the injection of $600 \mathrm{mg}$. should be determined by the production of the causative metabolite and the reconversion of methaemoglobin to haemoglobin; the shape of the curve would be an expression of the activity of these two processes. This curve could be mathematically predicted, assuming that the concentration of methaemoglobin is dependent upon the total number of electrons accepted from haemoglobin by an intermediate oxidation agent and that the level of such intermediate agent is proportional to the dose of the compound administered. ${ }^{9}$ Following $600 \mathrm{mg}$. prilocaine the maximum methaemoglobin concentration was reached after approximately three to four hours, falling thereafter gradually to attain normal levels in about 11 or 12 hours. If this relationship remains unchanged, repeated injections of $600 \mathrm{mg}$. at hourly intervals should result in a summation of the original curve, giving initially a progressive rise in methaemoglobin; then, however, the cumulative curve would level off, ending in a plateau that would persist as long as the injections were continued (Fig. 6). The level of this plateau would be directly proportional to the hourly dosage. 


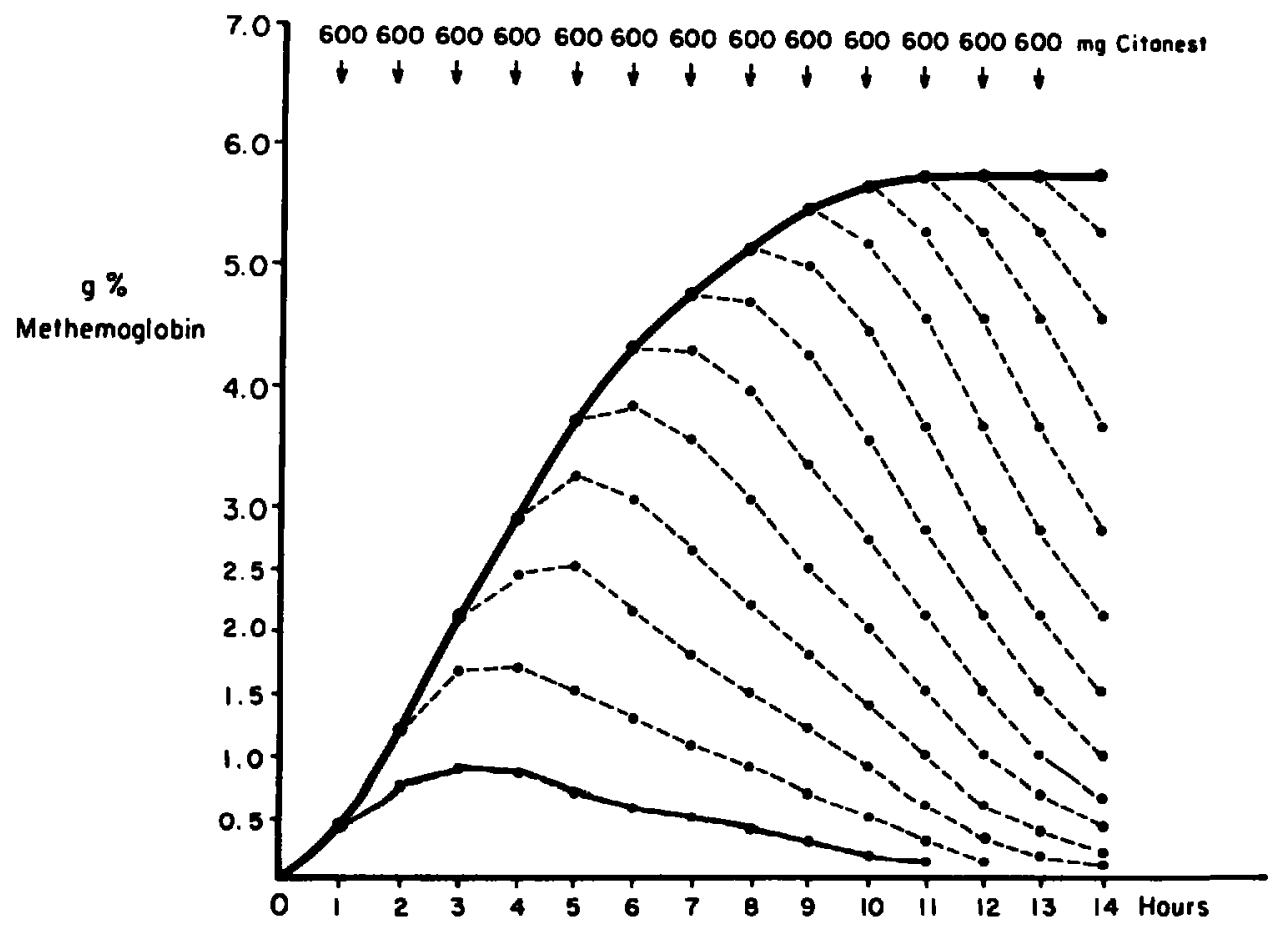

Frgure 6. Methaemoglobin levels following repeated injections of prilocaine. It was assumed that hourly injections of $600 \mathrm{mg}$. would be represented by superimposing every hour the methaemoglobin curve obtained from a single injection of $600 \mathrm{mg}$. prilocaine. The strong black line would then represent the resulting methaemoglobin level, rising at first, then turning toward a plateau or steady state.

During continuous epidural analgesia for pain relief, using a mechanical injection device controlled by an electronic timer ${ }^{12}$ we have indeed observed such a plateau or steady state in seven out of nine patients, even with a low dosage ranging from 50 to $100 \mathrm{mg}$. per square metre per hour (Fig. 7). In the other two patients the use of prilocaine was discontinued after 8 and 10 hours respectively, since the methaemoglobin values exceeded an arbitrary limit of $4.0 \mathrm{gm}$. per cent which we felt compatible with clinical safety. Neither of these two curves shows a distinct inclination toward a plateau. Therefore the assumption could be made that in some patients an inefficient enzymatic reversal mechanism may allow a continuing and excessive build-up of methaemoglobin. Lidocaine used in the same dosage for continuous epidural analgesia did not produce increased methaemoglobin, nor did the use of lidocaine subsequent to prilocaine in a similar dosage range interfere with the reversal of methaemoglobin.

The reduction of the oxygen-carrying capacity is presumably the only recognizable effect of this methaemoglobin-producing metabolite of prilocaine; there is no evidence in the literature that methaemoglobinaemia per se may lead to anaemia or renal damage. The oxygen transport system usually has a great reserve, but there are a number of circumstances where a reduction of the magnitude reported with prilocaine may give rise to concern. Vascular insuf- 


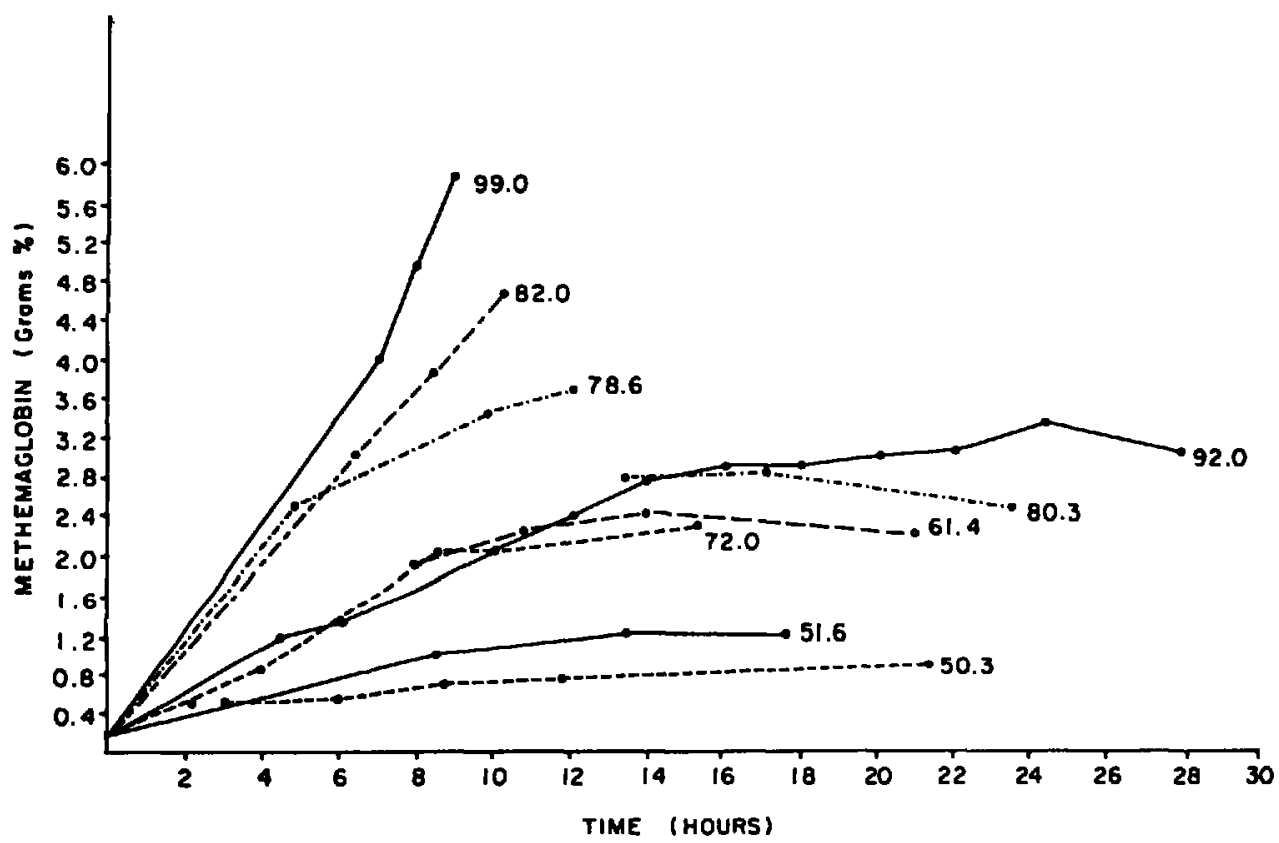

Frgune 7. Methaemoglobin levels observed in nine patients with hourly injections of the amount of prilocaine indicated at the end of each curve. Note the plateau in six cases and the turning towards a level in the seventh.

ficiency, particularly of the coronary and cerebral arteries, heart failure, shock, and especially anaemia may be mentioned here. It should be remembered that clinical signs of hypoxia become evident only with a very severe reduction in oxygen-carrying capacity and that a slight further decrease of oxygen may then cause sudden failure.

Continuous epidural analgesia has become a popular technique for obstetrical analgesia ${ }^{18}$ and is in our hospitals frequently maintained for over 8 hours and as long as 24 hours. When prilocaine was introduced, maternal and foetal cyanosis soon caused concern among obstetricians and anaesthetists. One cyanosed infant was stillborn; the mother had received about $1000 \mathrm{mg}$. prilocaine by intermittent epidural injection and was markedly cyanosed when the foetal heart ceased about the time the cervix had reached full dilatation. The full term infant weighed less than $6 \mathrm{lbs}$. and the placenta was unusually small. Methaemoglobin levels were not determined at that time. On checking the nurses' notes on admission to the newborn nursery, a remark about babies' having a poor colour or looking bluish was found in 5 of the other 14 babies born to mothers who had received prilocaine. In 56 babies admitted during the same period whose mothers had epidural analgesia with other local anaesthetic agents, notes about cyanosis were found in 4, giving an incidence of 1:14 compared to 1:3 with prilocaine. The nurses making these observations had no knowledge of the type of anaesthetic used.

We discontinued the use of prilocaine for obstetrical epidural analgesia at that time, but later administered continuous epidural analgesia with prilocaine to 
14 obstetrical patients, limiting the total dosage to $600 \mathrm{mg}$., with individual dosages of $120 \mathrm{mg}$. at about hourly intervals. At the time of delivery, the methaemoglobin content of maternal and foetal blood were of similar magnitude; the highest maternal value was $2.20 \mathrm{gm}$. per cent, the highest foetal level $2.03 \mathrm{gm}$. per cent methaemoglobin. ${ }^{11}$

\section{CONCLUSIONS AND SUMMARY}

1. With the dose of $600 \mathrm{mg}$. recommended by the manufacturer given in a single injection, the methaemoglobin content will usually not rise above $1 \mathrm{gm}$. per cent and cyanosis will be mild or absent. However, since the causative metabolite is part of the breakdown process of prilocaine, methaemoglobin will be formed with any dosage of prilocaine, no matter how small.

2. With continuous techniques using repeated injections there is a cumulative effect, and even if the dosage of each single injection is small, the methaemoglobin level may rise to values above the level of cyanosis. To avoid this it is recommended that dosages not exceed $600 \mathrm{mg}$. during a 12-hour period. Although with prolonged continuous use a plateau is reached and this plateau is related to the increments of prilocaine injected, there are wide individual variations, and dangerously high levels may occur.

3. Methaemoglobin interferes with the oxygen transport. While normal individuals have a remarkable tolerance to a reduction in functioning haemoglobin, this does not apply to situations where the oxygen transport is already critical. Particularly with severe anaemia, in cardiac failure, with coronary, cerebral or peripheral arterial insufficiency, and in patients in shock, even a moderate reduction in oxygen-carrying capacity may cause serious complications.

4. The placenta represents a critical situation for oxygen transport, and since prilocaine produces methaemoglobin in mother and infant, the oxygen-carrying capacity of maternal as well as foetal blood is reduced. The shift of the oxyhaemoglobin dissociation curve would further aggravate this situation. We concur with the opinion of Scott ${ }^{1}$ that prilocaine should not be used for continuous epidural analgesia in obstetrics.

5. It is well known that the recognition of cyanosis depends on lighting and on the astuteness of the observer. Cyanosis is usually seen with methaemoglobin concentrations of about $1.5 \mathrm{gm}$. per cent; subtle changes in colour may be observed with as little as $0.8 \mathrm{gm}$. per cent. This cyanosis is a less serious condition than that produced by hypoxia, where $5 \mathrm{gm}$. per cent of reduced haemoglobin must be present for clinical recognition. The magnitude of the hazard introduced by the frequent use of an agent likely to produce a more harmless form of cyanosis is not known; however, the standard of safety in modern anaesthesia is so high that we cannot afford to err in distinguishing between these two states of cyanosis. In practice, we believe, the methaemoglobin formation is as much of a limiting factor for the permissible dosage of prilocaine as the central nervous system toxicity may be for the use of lidocaine or other local anaesthetic agents. 


\section{RúsuMé}

La prilocaïne (Citanest), un nouvel agent anesthésique local, on l'a démontré, forme de la méthémoglobine. A la suite d'une seule injection de $600 \mathrm{mg}$, dose maxima recommandée par les manufacturiers, on a noté un taux de méthémoglobine de $0.93 \mathrm{gm}$. pour cent $( \pm .14)$ de trois à quatre heures après l'injection. Avec $900 \mathrm{mg}$. de prilocaïne, le taux s'est élevé à $1.97 \mathrm{gm}$. pour cent $( \pm .40)$ quatre heures après 'l'injection et, graduellement, il est revenu à la normale en deça de 10 à 14 heures. Dans la limite des tests, les taux de méthémoglobine étaient directement reliés aux doses de prilocaïne.

L'anesthésie épidurale continue avec la prilocaïne a occasionné une accumulation de méthémoglobine même avec des injections individuelles de $100 \mathrm{à} 200 \mathrm{mg}$. Dans ces circonstances, la méthémoglobine continue à s'élever à chaque nouvelle injection pour atteindre un plateau: chez deux des neuf malades, le méthémoglobine s'est élevée à environ $4 \mathrm{gm}$. pour cent avant d'atteindre un plateau et l'on a dû arrêter les injections. L'examen du sang maternel et du sang de l'enfant à sa naissance à la suite d'analgésie épidurale continue durant le travail avec la prilocaïne a révélé que le taux de méthémoglobine est le même dans les deux sangs.

La quantité de méthémoglobine réduit non seulement la capacité de transport de l'oxygène par le sang mais occasionne aussi une déviation de la courbe de dissociation de l'oxygène et diminue le quantité d'oxygène disponible au niveau tissulaire. Ainsi l'effet de la méthémoglobine est plus grand que celui d'une anémie d'importance égale. Chez des individus normaux, une méthémoglobine de 30 pour cent va entrainer une dyspnée d'effort; chez le chien, une réduction du contenu artériel en oxygène de 10 pour cent par la méthémoglobine, entraine une réaction compensatrice du débit cardiaque. Des taux de méthémoglobine de cette importance peuvent s'observer au cours de l'analgésie épidurale continue.

Si l'on veut éviter une cyanose visible, il ne faudrait pas dépasser la dose de $600 \mathrm{mg}$. par 12 heures. Chez les malades présentant des problèmes sur l'apport d'oxygène aux tissus vitaux, il faudrait employer la prilocaïne avec prudence; il serait préférable d'éviter son emploi au cours de l'épidurale continue durant le travail et l'accouchement. Il faut faire attention de ne pas sousestimer la signification de la cyanose au cours des suites opératoires chez les malades qui ont reçu de la prilocaïne.

\section{ACKNOWLEDGMENTS}

The authors wish to express their gratitude to Professor A. H. Neufeld (Department of Pathological Chemistry) for his support and personal interest in this study. The co-operation of the members of the Department of Anaesthesia and our surgical and obstetrical colleagues was much appreciated, particularly the understanding support of Dr. H. H. Allen (Department of Obstetrics and Gynaecology). A grant-in-aid and the continued support of Astra Pharmaceuticals (Canada) Ltd. are gratefully acknowledged. 


\section{REFERENCES}

1. WIEDLING, S. Citanest. Acta Anaesth. Scandinav. Suppl. XVI (1965).

2. AdAMson, D. H. \& SPOEREL, W. E. Propitocaine-Induced Methaemoglobinaemia in Continuous Epidural Analgesia. Can. Med. Ássoc. J. 94:658 (1966).

3. Scotr, D. B.; OWEN, J. A.; \& Richmond, J. Methaemoglobinaemia Due to Prilocaine. Lancet. 2:728 ( 1964 ).

4. Lund, P. C. \& CwIK, J. C. Citanest: A Clinical and Laboratory Study. Anesth. \& Analg. 44:712 (1965).

5. Evelyn, K. A. \& Macroy, H. T. Microdetermination of Oxyhaemoglobin, Methaemoglobin and Sulfhaemoglobin in a Single Sample of Blood. J. Biol. Chem. 126:655 (1938).

6. Darling, R. C. \& Rovgrton, F. J. W. The Effect of Methaemoglobin on the Equilibrium between Oxygen and Haemoglobin. Amer. J. Physiol. 137:56 (1942).

7. Pharmacologic Investigations on Citanest: Reports to Astra Laboratories, 1964.

8. GowDEY, C. W. Cardiac Output in Acute Experimental Methaemoglobinaemia. Can. J. Biochem. Physiol. 38:1411 (1960).

9. Bodansk, $O$. Methaemoglobinaemia and Methaemoglobin-Producing Compounds. Pharmacol. Rev. 3:144 (1951).

10. Golnhoff, N. \& WhEaton, R. Methylene-Blue-Induced Cyanosis and Acute Hemolyticanaemia Complicating the Treatment of Methaemoglobinaemia. J. Paediat. 58:86 (1961).

11. Adamson, D. H. \& Spozrez, W. E. Methaemoglobin Levels during Continuous Epidural Analgesia Using Prilocaine (Citanest). Acta Anaesth. Scandinav. Suppl. XXIII, 379 (1966).

12. Cox, J. M. R. \& Spoerer, W. E. Continuous Epidural Analgesia: The Use of an Intermittent Injection Device. Can. Anaes. Soc. J. 11 :72 (1964).

13. Kandez, Patricia F.; Sporrer, W. E.; \& KnnCH, R. A. H. Continuous Epidural Analgesia for Labour and Delivery. Can. Med. Assoc. J. 95:947 (1966). 